\title{
HUBUNGAN ANTARA POLA ASUH ORANG TUA DENGAN PERKEMBANGAN MENT AL ANAK PADA PROSES TUMBUH KEMBANG DI SD BENTAKAN 1 SUKOHARJO
}

\author{
Oleh : \\ Dinar Ariasti ${ }^{1}$ Tunjung Sri Yulianti ${ }^{2}$, Ana Pratiwi $^{3}$
}

\begin{abstract}
Background. one part of child development is mental development. Mental development is the increasing ability to think, feel, do various situations everyday life as well as increased ability to see ourselves and others. Mental development of a child is influenced by internal factor and eksternal factor. Internal factor include genetic and hormonal influenced. While external factor include nutrition, environment and affection both the family and the people around him. From observations of public researches tend to not pay attention to the relationship between parenting and development mental. People tend not to care about the parenting that they impose on their child. From the initial study showed that four people not to care about the proper upbringing for their children.

The purpose of this study was to determine the relationship of parenting and mental development of children in the growth process in SD Bentakan I Sukoharjo.

Subjects were children from first and second class under the age of 6-7 years in SD Bentakan I Sukoharjo. Sampling is done with saturated sampling technique, namely by taking all members of the population being sampled because the population is small.

Methods in this study is a correlation study, case-control approach. Data were obtained by questionnaire and observation method to observe parenting method and mental development in children aged 6-7 years. The data have been collected and analyzed with the chi square test with $p=0.05$.

The results of the study there were parenting parents most widely applied is a democratic parenting style that is 23 parents $(57,5 \%)$, whereas parenting is the least permissive parenting as many as 4 parents $(10 \%)$. After being tested by Chi-Square SPSS version 16.0 with $\alpha=5 \%(0.05)$ of 0000 thus obtained $p$ value of $p<0.05$, which means that $\mathrm{Ho}$ is rejected and Ha accepted.

The conclusion of this study is that there is a relationship between parentingand mental development of children in the growth process in SD Bentakan I Sukoharjo.
\end{abstract}

Keyword : parenting, mental development

\section{PENDAHULUAN}

Pertumbuhan adalah bertambahnya ukuran fisik (anatomi) dan struktur tubuh dalam arti sebagian atau seluruhnya karena adanya multiplikasi dan pertambahan ukuran sel berarti ada pertambahan secara kuantitatif dan hal tersebut terjadi sejak terjadinya konsepsi. Jadi pertumbuhan lebih ditekankan pada pertambahan ukuran fisik seseorang, yaitu menjadi lebih besar atau lebih matang bentuknya. Pertumbuhan pada masa anak-anak mengalami perbedaan yang bervariasi sesuai dengan bertambahnya usia anak. (Nursalam, 2005) 
Sedangkan perkembangan anak adalah bertambahnya kemampuan dan struktur atau fungsi tubuh yang kompleks dalam pola yang teratur, dapat diperkirakan dan diramalkan sebagai hasil dari proses diferensiasi sel, jaringan tubuh, organ-organ dan sistemnya yang terorganisasi. Aspek perkembangan bersifat kuantitatif. (Nursalam, 2005) Salah satu bagian dari perkembangan anak yaitu perkembangan mental. Perkembangan mental adalah bertambahnya kemampuan memikirkan, merasakan, melakukan berbagai situasi kehidupan seharihari serta bertambahnya kemampuan dalam memandang diri sendiri dan orang lain. (Nursidik, 2008)

Rasa dan perasaan merupakan salah satu potensi yang khusus yang dapat mempengaruhi mental anak. Pada anak-anak telah terjadi perkembangan mental yang relatif rendah (abstrak). Anak belum menguasai nilai-nilai abstrak yang berkaitan dengan benar-salah dan baik-buruk. Semakin bertumbuh dan berkembang fisik dan psikisnya, anak mulai diperkenalkan terhadap nilai-nilai, ditunjukkan hal yang boleh dan hal yang tidak boleh dilakukan. Dalam hal ini keluarga mempunyai peranan penting karena dipandang sebagai sumber utama dan proses sosialisasi. (Rasjidi, 2009) Perkembangan mental seorang anak dipengaruhi oleh faktor internal dan eksternal. Faktor internal meliputi genetika dan pengaruh hormon, sedangkan faktor eksternal meliputi asupan nutrisi, lingkungan dan kasih sayang baik keluarga maupun orang disekitarnya. (Nursalam, 2005)

Dari pengamatan peneliti selama ini yang berkembang di masyarakat cenderung belum memperhatikan ada tidaknya hubungan antara pola asuh dan perkembangan mental. Masyarakat cenderung tidak peduli dengan pola asuh yang mereka terapkan pada anaknya. Hal ini terlihat dari hasil survey pendahuluan terhadap 5 orang tua tentang pola asuh yang mereka terapkan pada anaknya. Dari kelima orang tua tersebut didapatkan hasil bahwa empat orang tua cenderung tidak peduli tentang perlunya pola asuh yang tepat bagi anak-anaknya. Selain itu dari hasil pengamatan awal perkembangan mental anak dari satu segi yaitu kemampuan membaca terlihat bahwa, dari 5 anak ada tiga anak yang perkembangannya baik (dapat membaca dan 2 anak kurang baik (tidak dapat membaca).

\section{TUJUAN PENELITIAN}

Untuk mengetahui hubungan antara pola asuh orang tua dan perkembangan mental anak pada proses tumbuh kembang di SD Bentakan I Sukoharjo.

\section{DESAIN PENELITIAN}

Pada penelitian ini penulis menggunakan desain penelitian korelasi dengan pendekatan metode cross sectional untuk mengetahui hubungan antara pola asuh orang tua sebagai variabel bebas dan perkembangan mental anak pada proses tumbuh kembang di SD Bentakan I Sukoharjo sebagai variabel terikat.

\section{POPULASI, SAMPEL DAN TEKNIK SAMPLING}

Populasi dalam penelitian ini adalah siswa kelas 1 dan 2 yang berusia 6 7 tahun yang bersekolah di SD Bentakan I Sukoharjo.

Peneliti mengambil sampel sesuai dengan populasi yang ada yaitu sebanyak 40 siswa kelas 1 dan 2 berusia 6-7 tahun dengan teknik sampling jenuh yaitu dengan mengambil semua anggota populasi menjadi sampel, karena jumlah populasi yang sedikit.

Peneliti menggunakan alat ukur kuesioner dan lembar observasi 
untuk mengetahui pola asuh dan tingkat perkembangan mental anak.

\section{HASIL PENELITIAN}

Penelitian ini dilakukan mulai tanggal 24-29 Mei 2013 dengan jumlah responden sebanyak 40 orang. Tempat penelitian adalah SD Bentakan I Sukoharjo. Di bawah ini akan dipaparkan hasil penelitian tentang hubungan antara pola asuh orang tua dan perkembangan mental anak pada proses tumbuh kembang di SD Bentakan I Sukoharjo.

Tabel1. Distribusi Frekuensi pola asuh orang tua di SD Bentakan I Sukoharjo

\begin{tabular}{ccc}
\hline $\begin{array}{c}\text { Tingkat } \\
\text { Pengetahuan }\end{array}$ & $\mathrm{F}$ & $\%$ \\
\hline Demokratis & 23 & $57,5 \%$ \\
\hline Otoriter & 8 & $20 \%$ \\
\hline Permisif & 4 & $10 \%$ \\
\hline Penelantar & 5 & $12,5 \%$ \\
\hline Jumlah & 40 & $100 \%$ \\
\hline
\end{tabular}

Dari tabel di atas diperoleh data yaitu pola asuh orang tua yang paling banyak diterapkan oleh orang tua adalah pola asuh demokratis yaitu 23 orang $(57,5 \%)$, sedangkan pola asuh paling sedikit adalah pola asuh permisif yaitu sebanyak 4 orangtua (10\%)

Tabel2. Distribusi Frekuensi

Perkembangan Mental Anak di SD Bentakan I Sukoharjo

\begin{tabular}{ccc}
\hline $\begin{array}{c}\text { Perkembangan } \\
\text { Mental Anak }\end{array}$ & $\mathrm{F}$ & $\%$ \\
\hline Baik & 27 & 67,5 \\
\hline Tidak baik & 13 & 32,5 \\
\hline Jumlah & 40 & $100 \%$ \\
\hline
\end{tabular}

Dari tabel di atas diperoleh data yaitu anak yang mengalami perkembangan mental baik atau dapat melakukan $\geq 13$ test sejumlah 27 anak $(67,5 \%)$ sedangkan yang mengalami perkembangan tidak baik atau dapat melakukan $\leq 12$ test sejumlah 13 siswa (32,5\%).

Dari hasil penelitian hubungan antara pola asuh orang tua dan perkembangan mental anak pada proses tumbuh kembang di SD Bentakan I Sukoharjo diperoleh hasil uji dengan Chi-Square diperoleh bahwa $x^{2}$ hitung sebesar 8,19. Sedangkan $x^{2}$ tabel 7,815 , berarti Ho ditolak dan $\mathrm{Ha}$ diterima, sehingga dapat ditarik kesimpulan bahwa ada hubungan antara pola asuh orang tua dan perkembangan mental anak pada proses tumbuh kembang di SD Bentakan I Sukoharjo.

\section{PEMBAHASAN}

1. Pola Asuh Orang Tua

Dari hasil tabel 1 diperoleh data yaitu pola asuh orangtua yang paling banyak diterapkan orangtua adalah pola asuh demokratis yaitu sebanyak 23 orangtua $(57,5 \%)$. Sedangkan pola asuh yang paling sedikit diterapkan orangtua adalah pola asuh permisif yaitu sebanyak 4 orangtua (10\%).

Menurut Tedjasaputra (2008), pola asuh orangtua yang paling tepat dan banyak diterapkan dalam keluarga adalah pola asuh demokratis. Pola asuh demokratis adalah pola pengasuhan dimana orangtua mendorong anak untuk menjadi mandiri, tetapi tetap memberikan batasan-batasan (aturan) serta mengontrol perilaku anak.

2. Perkembangan Mental Anak Dari hasil tabel 2 diperoleh data yaitu anak yang mengalami perkembangan mental yang baik atau dapat melakukan $\geq 13$ test sejumlah 27 anak (67,5\%), sedangkan anak yang mengalami perkembangan mental tidak baik atau dapat melakukan $\leq 12$ test sejumlah 13 siswa (32,5\%). 
Menurut Wong (2004), tahapan perkembangan pada anak usia 67 tahun dapat diketahui dengan : mengembangkan konsep angka, menghitung 13 uang logam, mengetahui pagi atau siang, mendefinisikan obyek umum seperti garpu dan kursi dalam istilah penggunannya, mematuhi 3 macam perintah sekaligus, mengetahui tangan kanan dan tangan kiri, mengatakan bagaimana yang bagus dan bagaimana yang jelek dari segi gambar wajah, menggambarkan objek dalam gambar daripada menyebutnya satu-persatu, masuk kelas I, memperhatikan bagian tertentu dari gambar yang hilang, dapat meniru gambar permata, ulangi tiga angka kebelakang, mengulang konsep waktu, masuk kelas 2, lebih mekanis dalam membaca. Menurut Darsono (2008), perkembangan mental seorang anak dipengaruhi oleh keadaan fisik sesuai usia, pendidikan yang diterima baik formal maupun non formal atau pola asuh di rumah dan keadaan lingkungan sosial budaya.

3. Hubungan Pola Asuh Orang Tua dengan Perkembangan Mental

Anak

Dari hasil penelitian hubungan antara pola asuh orang tua dan perkembangan mental anak pada proses tumbuh kembang di SD Bentakan I Sukoharjo diperoleh hasil uji dengan Chi-Square diperoleh bahwa $x^{2}$ hitung sebesar 8,19 . Sedangkan $x^{2}$ tabel 7,815, berarti Ho ditolak dan $\mathrm{Ha}$ diterima, sehingga dapat ditarik kesimpulan bahwa ada hubungan antara pola asuh orang tua dan perkembangan mental anak pada proses tumbuh kembang di SD Bentakan I Sukoharjo.
Hasil penelitian menunjukkan bahwa pola asuh yang paling banyak diterapkan orangtua adalah pola asuh demokratis. Pola asuh demokratis yang banyak diterapkan orangtua dapat mempengaruhi perkembangan mental anak menjadi baik yaitu sebesar $70,37 \%$. Hal ini dapat terjadi karena orang tua dengan pola asuh demokratis cenderung mengutamakan kepentingan anak, tetapi juga tetap mengarahkan dan mengendalikan mereka. Orang tua tipe ini selalu memberi kesempatan pada anak untuk memilih dan menentukan sesuatu. Namun orangtua tetap memberikan penjelasan tentang keuntungan dan kerugian apa yang telah mereka pilih. Dengan kesempatan yang diberikan orang tua, anak akan lebih kreatif dan berpikiran maju dalam menentukan sesuatu. Anak juga menjadi lebih berani dalam mencoba hal-hal baru sehingga mereka memiliki banyak pengalaman.

Sedangkan pola asuh yang dapat mempengaruhi perkembangan mental anak menjadi tidak baik, terlihat pada pola asuh penelantar yaitu sebesar $30,77 \%$. Hal ini dikarenakan orangtua cenderung kurang dalam memberikan waktu dan biaya dalam memenuhi kebutuhan anak. Orang tua tipe ini lebih tidak peduli pada keadaan anak. Hal ini terjadi kemungkinan karena keadaan ekonomi, pekerjaan orangtua dan jumlah anak dalam keluarga tersebut. Anak yang dibesarkan dengan pola asuh penelantar, cenderung tidak peduli pada apa yang telah mereka lakukan, mereka juga tidak peduli pada hal-hal baru atau pengalaman baru yang mereka dapatkan. Sehingga perkembangan mental maupun intelektualnya pun 
menjadi lebih terlambat daripada anak-anak yang mendapatkan pengarahan dari orang tuanya. Menurut Shanti (2006), pola asuh yang diterapkan orangtua tidak selamanya efektif, malah terkadang dampaknya pada anak bukannya baik tapi buruk. Pola asuh yang terlalu proktektif, atau memanjakan anak atau bahkan tidak peduli pada anak tentu menyebabkan anak menjadi tidak kreatif, selalu tergantung pada orang lain dan perkembangan mentalnya terganggu.

Hasil penelitian terlihat jelas bahwa pola asuh demokratis dapat mempengaruhi perkembangan mental anak menjadi baik yaitu sebesar $70,37 \%$. Sedangkan pola asuh penelantar dapat dapat mempengaruhi perkembangan mental anak menjadi tidak baik yaitu sebesar $30,77 \%$.

\section{KESIMPULAN}

Dari hasil penelitian hubungan antara pola asuh orang tua dan perkembangan mental anak pada proses tumbuh kembang di SD Bentakan I Sukoharjo diperoleh hasil uji dengan Chi-Square diperoleh bahwa $x^{2}$ hitung sebesar 8,19. Sedangkan $x^{2}$ tabel 7,815 , berarti Ho ditolak dan $\mathrm{Ha}$ diterima, sehingga dapat ditarik kesimpulan bahwa ada hubungan antara pola asuh orang tua dan perkembangan mental anak pada proses tumbuh kembang di SD Bentakan I Sukoharjo.

\section{SARAN}

1. Bagi Orang Tua

Orangtua diharapkan lebih bijaksana dalam mendidik dan mengasuh anaknya. Hal itu dapat diperlihatkan dengan menentukan pola asuh yang tepat bagi anaknya, salah satunya pola asuh demokratis. Pola asuh yang senantiasa memberikan kebebasan pada anak tetapi tetap memberikan batasan-batasan tertentu.

2. Bagi Pihak Sekolah

Pihak sekolah diharapkan lebih memperhatikan perkembangan mental anak didiknya. Hal ini dapat dilakukan dengan melakukan pendekatan pada masing-masing anak didik untuk mengetahui kekurangan dan kelebihan masing-masing anak.

3. Bagi Peneliti Selanjutnya

Diharapkan penelitian ini dapat dikembangkan lebih lanjut oleh peneliti-peneliti lain yang berhubuhan dengan perkembangan mental atau pola asuh orang tua.

\section{DAFTAR PUSTAKA}

Budiarto, Eko. Biostatistika untuk Kedokteran dan Kesehatan Masyarakat. Jakarta: EGC, 2002

Baharudin. Pendidikan dan Psikologi Perkembangan. Jogjakarta: ArRuzy Media, 2009

Hidayat, A. Aziz Alimul. Riset Keperawatan dan Teknik Penulisan IImiah.Edisi II. Jakarta: Salemba Medika, 2008.

Nursalam, Rekawati Susilaningrum dan Sri Utami.Asuhan Keperawatan Bayi dan Anak.Jakarta: Salemba Medika, 2008.

Potter, Patricia A dan Anne Griffin Perry. Buku Ajar Fundamental Keperawatan Konsep, Proses dan Praktik. Edisi IV. Alih Bahasa Yasmin Asih, et al. Jakarta: EGC, 2005.

Riwidikdo, Handoko. Statistik Kesehatan.Yogyakarta: Mitra Cendikia Press, 2007.

Santosa, R. Gunawan. Statistik. Yogyakarta: Andi, 2004 
Soetijiningsih, dan IGN. N. Gde Ranuh. Tumbuh Kembang Anak. Jakarta: EGC, 2014.

Wong, Donna L. Pedoman Klinis Keperawatan Pediatrik.Edisi IV. Alih Bahasa Monica Ester.Jakarta : EGC, 2003.

Nursidik, Yahya. "Perkembangan". http://definisi perkembangan. Htm".2008. diakses tanggal 12 April 2013.

Rasjidi, Mochtar. "Kesehatan Mental Anak".

http://www.halaguide.info.htm. 2009. Diakses 12 April 2013

Shanti, Theresia Indira."Pola Asuh Efektif, Pola Asuh Penuh Cinta". $\quad$ http://www. Tabloid.nakita. com.htm. 2008. Diakses 14 April 2013

Tedjasaputra, Myke S."Pola Asuh Tepat untuk Semua Tipe Anak". $\quad$ http://www. Tabloid.nakita. com.htm. 2008. Diakses 14 April 2013

1 Dosen AKPER Panti Kosala Surakarta.

2 Dosen AKPER Panti Kosala Surakarta.

3 Mahasiswa AKPER Panti Kosala Surakarta 